\title{
STRATEGI NAFKAH PENAMBANG PASIR DUSUN CITERATE DESA UJUNG GENTENG KABUPATEN SUKABUMI PROVINSI JAWA BARAT
}

\author{
Strategy Living Miners Sand Dusun Citerate, Ujung Genteng Village, Sukabumi, West Java \\ Hilda Nurul Hidayati*), Ibnu Phonna Nurdin, Bayu Budiandrian, Gadri Ramadhan Attamimi, dan Rohayati \\ Program Studi Sosiologi Pedesaan Fakultas Ekologi Manusia, Sekolah Pascasarjana IPB \\ *Email: hildanurulhidayati@yahoo.com
}

\begin{abstract}
The existence of natural resources in the area to give a decision for the people to use it as a business. In addition, if it is found that the main livelihood is not enough to daily needs, so it is done utilizing existing resources. This situation also occurs in the location of a field study that is in the Village Ujung Genteng Ciracap District of Sukabumi precisely in Dusun Citerate. Based on the state of the resources that have been described, this study aims to analyze the forms of livelihood strategies adopted by society, social stratification is formed as a result of livelihood strategies, and strategies to survive or resilience as a result of environmental change. The method used in this study is a qualitative method. The collection of information is done by in-depth interviews with local community leaders. The study shows that the form of livelihood strategies taken is diversification and migration (Scoones 1998). The livelihood strategies of social stratification that eventually form the top layer of sand occupied by miners who had an area of 2 hectares, the middle layer is occupied by sand mining land is not too wide and is located next to the house, while the bottom layer of sand occupied by workers. The resilience is taken when changes in the environment that make variations and move (migrate) (Chambers and Conway 1991).
\end{abstract}

Keywords: livelihood strategies, migration, resilience, social stratification, ujung genteng village

\begin{abstract}
ABSTRAK
Keberadaan sumber daya alam di daerah tersebut untuk memberikan keputusan bagi orang-orang untuk menggunakannya sebagai sebuah bisnis. Selain itu, jika ditemukan bahwa mata pencaharian utama tidak cukup untuk kebutuhan sehari-hari, sehingga hal itu dilakukan memanfaatkan sumber daya yang ada. Situasi ini juga terjadi di lokasi studi lapangan yang ada di Desa Ujung Genteng Ciracap Kabupaten Sukabumi tepatnya di Dusun Citerate. Berdasarkan keadaan sumber daya yang telah dijelaskan, penelitian ini bertujuan untuk menganalisis bentuk strategi penghidupan yang diadopsi oleh masyarakat, stratifikasi sosial terbentuk sebagai hasil dari strategi mata pencaharian, dan strategi untuk bertahan hidup atau ketahanan sebagai hasil dari perubahan lingkungan. Metode yang digunakan dalam penelitian ini adalah metode kualitatif. Pengumpulan informasi dilakukan dengan wawancara mendalam dengan tokoh masyarakat setempat. Studi ini menunjukkan bahwa bentuk strategi mata pencaharian yang dilakukan adalah diversifikasi dan migrasi (Scoones 1998). Strategi penghidupan stratifikasi sosial yang akhirnya membentuk lapisan atas pasir ditempati oleh penambang yang memiliki area seluas 2 hektar, lapisan tengah ditempati oleh lahan tambang pasir tidak terlalu lebar dan terletak di sebelah rumah, sedangkan lapisan bawah pasir ditempati oleh pekerja. Ketahanan diambil ketika perubahan lingkungan yang membuat variasi dan bergerak (migrasi) (Chambers dan Conway 1991).
\end{abstract}

Kata kunci: ketahanan, migrasi, strategi penghidupan, stratifikasi sosial, Ujung Genteng desa

\section{PENDAHULUAN}

\section{Latar Belakang}

Dusun Citerate merupakan dusun yang berdekatan dengan
Kantor Desa Ujung Genteng. Berdasarkan hasil pengamatan diketahui batas-batas antar dusun yaitu batas Dusun Citerate dengan Dusun Cigebang adalah jembatan yang di bawahnya mengalir sungai kecil sedangkan batas antara Dusun Citerate dengan Dusun Ujung Genteng adalah tugu 
rudal. Mata pencaharian masyarakat yang terlihat di dusun ini adalah penambang pasir, buruh tambak, petani, dan pedagang. Sejauh kajian ini dilakukan mata pencaharian sebagai penambang pasir adalah yang paling menarik untuk dianalisis. Meski sejarah berdirinya tambak di dusun ini juga menuai banyak kontroversi namun penambang pasir lebih menarik karena berkaitan dengan isu lingkungan dan politik.

Banyaknya pasir akibat air laut yang surut membuat masyarakat Dusun Citerate tergerak untuk memanfaatkannya sebagai sumber penghidupan ditambah lahan pertanian mereka yang vacuum. Awalnya salah seorang warga sedang membangun rumah kemudian batu bata untuk membangun rumah habis dan mereka tidak kehabisan akal untuk mengambil pasir di sekitar rumahnya untuk dibuat batu bata. Hasilnya batu bata yang terbuat dari pasir tersebut kokoh dan bagus. Berawal dari itulah masyarakat mulai memanfaatkan pasir sebagai sumber penghidupan mereka. Seiring berjalannya waktu mereka mulai mengkavling pasir-pasir miliknya bahkan beberapa diantara mereka mampu membeli pasir laut dengan luas sekitar 2 hektar. Terhitung hingga tahun 2014 penambang pasir di Dusun Citerate sebanyak 50 pemilik tambang pasir. Banyaknya pemilik tambang pasir membuat mereka terdorong untuk membuat kelompok penambang pasir yaitu Ikatan Penambang Pasir Citerate (IPPC).

Sekilas terlihat bahwa tambang pasir sangat memberikan keuntungan pada perekonomian masyarakat di Dusun Citerate. Namun selalu ada dampak yang ditimbulkan jika diambil secara berlebihan. Pasir yang sudah habis ditambang akan membentuk kubangan air dan menjadi endemik nyamuk. Bahkan menurut informan, masyarakat Dusun Citerate pernah terkena malaria. Setelah diteliti endemik nyamuk malaria ditengarai dari kubangan air hasil tambang pasir. Jika dilihat lebih jauh, pada kenyataanya tambang pasir ini hanya menguntungkan masyarakat dengan modal ekonomi tinggi. Masyarakat dengan ekonomi rendah hanya menjadi buruh tambang dan pada saat-saat tertentu menjadi petani atau pedagang sebagai penghasilan tambahan. Berdasarkan latar belakang maka pertanyaan rinci dari kajian ini adalah sebagai berikut:

1. Sejauh mana sumber daya alam pasir sebagai strategi nafkah bagi masyarakat di Dusun Citerate?

2. Sejauh sumber daya alam pasir membentuk pelapisan sosial dalam masyarakat di Dusun Citerate?

3. Sejauh mana strategi bertahan hidup atau resiliensi yang diambil masyarakat dalam menghadapi perubahan lingkungan dari sumber daya alam pasir?

\section{Tujuan}

Tujuan tulisan ini adalah sebagai berikut:

1. Menganalisis sumber daya alam pasir sebagai strategi nafkah bagi masyarakat di Dusun Citerate.

2. Menganalisis pembentukan pelapisan sosial akibat adanya sumber daya alam pasir di Dusun Citerate.

3. Menganalisis strategi bertahan hidup atau resiliensi yang diambil masyarakat dalam menghadapi perubahan lingkungan dari sumber daya alam pasir.

\section{GAMBARAN UMUM}

\section{Kondisi Geografi dan Demografi}

Dusun Citerate adalah salah satu dusun di Desa Ujung Genteng Kecamatan Ciracap Kabupaten Sukabumi. Secara administratif Desa Ujung Genteng berbatasan dengan Desa Gunung Batu, Kecamatan Waluran di Sebelah Utara, Samudara Hindia di Selatan, Desa Cikangkung, Kecamatan Surade di Timur, dan Desa Pangumbahan, Kecamatan Ciracap di Barat. Desa Ujung Genteng merupakan pemekaran Desa Gunung Batu sejak tahun 2008 berdasarkan Perda Kabupaten Sukabumi No. 8 tahun 2008.

Jumlah penduduk Desa Ujung Genteng pada tahun 2013 mencapai 4.569 jiwa dengan jumlah Kepala Keluarga (KK) adalah $1.277 \mathrm{KK}$. Jumlah penduduk laki-laki sebanyak 2.381 orang lebih banyak daripada perempuan sebanyak 2.188 orang (sex ratio: 1,09). Penduduk di Desa Ujng Genteng didominasi oleh penduduk berusia produktif (1560 tahun).

\section{Struktur Sosial Dusun Citerate}

\section{Pelapisan Sosial Masyarakat Dusun Citerate}

Masyarakat Dusun Citarate berasal dari dua suku yang berbeda yakni Jawa dan Sunda. Meskipun berbeda etnik, tingkat kekerabatan terjalin sangat tinggi di antara masyarakat. Pelapisan sosial yang tertinggi adalah kepala pemerintahan lokal (Bapak Kepala Desa), hal ini dapat dimaklumi karena kepala Desa menjadi pemimpin di Desa tersebut dan sebagai orang yang dihormati atas kedudukannya. Kemudian lapisan sosial setelah kepala Desa adalah para tetua adat. Para tetua adat memiliki sisi kharismatik yang disegani oleh masyarakat dusun. Kemudian lapisan paling bawah ialah masyarakat biasa. Pada lapisan ini jumlahnya sangat banyak karena mayoritas masyarakat berada pada lapisan bawah. Pekerjaan mereka bervariasi seperti bertani, menambang pasir, bekerja pada tambak udang, berjualan di warung dan lainnya.

Sistem kepemimpinan lokal di Desa Ujung Genteng dijalankan oleh seorang Kepala Desa, kemudian di tiap tiap dusun, sistem pemerintahan diwakilkan oleh kepala dusun yang mempunyai fungsi membantu kinerja dari kepala Desa.Selain itu, keberadaan BKD menjadi penting untuk membantu percepatan pembangunan di desa ujung Genteng (khususnya dusun citarate). Menurut Yinger dalam Narwoko (2010), terdapat dua sistem pelapisan dalam masyarakat, yaitu yang bersifat tertutup (closed social startification) dan bersifat terbuka (opened social stratification). Untuk melihat sejauh mana keterbukaan sebuah sistem sosial bisa diukur dari mudah tidaknya seseorang yang mempunyai status tertentu memperoleh status dalam lapisan yang lebih tinggi. Sistem pelapisan di didusun citarate terjadi secara terbuka.Menjadi Kepala desa di ujung genteng diperoleh jika seseorang telah memenuhi syarat syarat yang berlaku. Syarat-syarat tersebut berlaku untuk semua individu yang mencalonkan diri sebagai kepala Desa. Demikian halnya pemilihan kepala dusun, diadakan musyawarah untuk menetapkan kepala dusun.

Keberadaan Kelembagaan adat di Dusun Citerate berjalan baik. Para tetua adat yang memiliki sisi kharismatik berperan penting dalam menjaga keutuhan persatuan di 
dusun Citerate. Setiap kali terjadi pertikaian sesama warga, tetua adat menjadi penengah dan berhasil memberikan solusi yang terbaik diantara kedua belah pihak. Sehingga permasalahan itu selesai dalam waktu yang relatif singkat. Pada kelembagaan adat juga berlaku sistem pelapisan sosial terbuka sesuai mekanisme yang berlaku. Meskipun terdapat dua etnis yang berbeda, namun hal ini tidak menyebabkan perpecahan diantara masyarakat.

\section{Solidaritas Sosial, Keyakinan dan Pernikahan}

Durkheim membedakan antara solidaritas mekanik dan organik. Pada solidaritas mekanik biasanya masih berjalan pada masyarakat pedesaan. Solidaritas mekanik disebut juga solidaritas yang memiliki tingkat kekerabatan, kolektivitas yang masih tinggi.

Masyarakat Dusun Citerate menerapkan asas gotong royong untuk membantu sesama warganya membangun rumah. Bentuk gotong royong di Dusun Citerate bersifat kekeluargaan dalam artian tidak ada pungutan biaya sedikitpun kepada pemilik rumah, biaya hanya dikeluarkan untuk pembayaran jasa tukang dalam membuat rumah. Terdapat perbedaan antara etnis jawa dan sunda di dalam kebiasaan dalam memenuhi undangan hajatan. Biasanya Etnis Jawa ketika diundang,yang diundang saja datang. Sedangkan etnis sunda dalam memenuhi undangan hajatan, datang bersama keluarga kecil (Ayah, Ibu, Anak). Selain itu, jika ada seseorang warga yang meninggal dunia akan diumumkan melalui mesjid, dan segera kaum perempuan membawakan beras ataupun makanan ke rumah duka. Ini mengindikasikans bahwa solidaritas yang terjalin sesama warga sangat erat. Solidaritas mekanik yang dipegang teguh oleh masyarakat dusun Citerate membuat kehidupan mereka saling bergantung satu sama lain. Masyarakat dusun Citerate mayoritas beragama islam. keberadaan pondok pesantren di Dusun memberikan gambaran bagaimana masyarakat dusun menerima dengan baik adanya kegiatan keagamaan.Pernikahan yang dilaksanakan di dusun citarate seperti halnya di tempat tempat lain. meskipun dusun Citerate memiliki 2 etnis yang berbeda, namun tidak ada larangan untuk menikahi masyarakat yang berlainan etnis.Ini memperlihatkan bahwa kekerabatan yang terjalin diantara dua etnis ini sangat baik hingga saat ini.

\section{Kelembagaan Formal}

Kelembagaan formal yang ada di Dusun Citerate salah satunya ialah Ikatan Penambang pasir Citarate. Lembaga yang diberi izin pada tahun 1992 oleh Dinas Pertambangan Kabupaten Sukabumi ini merupakan wadah bagi siapa saja yang terlibat dalam mengelola penambangan pasir. Mulai dari buruh, pemilik lahan dan pengumpul.Salah satu aturan yang diterapkan dalam IPPC ini adalah untuk mengatasi masalah dalam tapal batas. Jika ditemukan masalah penggali pasir yang melampaui batas galiannya (kepemilikan lahan), maka cara untuk menyelesaikannya adalah dengan bermusyawarah sesama anggota IPPC. Oleh karena itu, keseimbangan sistem yang terjadi di dalam struktur kelembagaan ini tetap berjalan sebagaimana mestinya.

\section{Kerangka Teoritis}

Pada dasarnya pekerjaan utama masyarakat Dusun Citerate adalah sebagai petani dan sebagian nelayan. Namun pendapatan yang diperoleh dari dua mata pencaharian tersebut tidak cukup untuk memenuhi kebutuhan sehari- hari sehingga mereka mencari alternatif pekerjaan lain yang bisa menopang hidup. Selain itu munculnya pasir laut dari surutnya air laut menggerakan masyarakat Dusun Citerate untuk memanfaatkannya sebagai suatu usaha. Pemanfaatan sumberdaya alam yang dilakukan oleh masyarakat Dusun Citerate dapat dikatakan sebagai strategi nafkah. Strategi nafkah menurut Conway dan Chambers (1991) adalah livelihood compromise the capabilities, assets (stores, resources, claim, and acces) and activities required for a means of living.

Kajian strategi nafkah dapat dibahas melalui pendekatan bentuk-bentuk strategi nafkah. Berdasarkan bentuk strategi nafkah, Scoones (1998) membaginya menjadi tiga yaitu:

1. Intensifikasi pertanian yaitu antara modal dan tenaga kerja.

2. Diversifikasi yaitu antara pilihan aktif untuk berinvestasi dalam diversifikasi secara akumulasi dan reinvestasi. Diversifikasi ditujukan untuk mengatasi kesulitan sementara atau adaptasi yang lebih permanen dari kegiatan mata pencaharian, ketika pilihan lain gagal untuk memberikan penghidupan.

3. Migrasi yaitu antara penyebab migrasi yang berbeda (misalnya perpindahan sukarela dan tidak sukarela), pengaruh (misalnya investasi di bidang pertanian, perusahaan atau konsumsi di rumah atau migrasi satu tempat) dan pola perpindahan (misalnya ke atau dari tempat yang berbeda).

Strategi nafkah yang dimiliki masyarakat seringkali tidak dapat dilakukan secara terus menerus. Hal tersebut dikarenakan sumberdaya yang dimiliki terbatas sehingga memerlukan pertahanan yang bisa menyambung hidup masyarakat. Pertahanan yang dilakukan dikenal dengan istilah strategi bertahan hidup atau resiliensi yang merupakan kemampuan kelompok atau masyarakat untuk mengatasi tekanan eksternal dan gangguan sebagai akibat dari perubahan sosial, politik, dan lingkungan (Jansen 2007 dalam Cote 2012). Bentuk-bentuk strategi nafkah menurut Chamber dan Conway (1991) adalah sebagai berikut:

1. Berhemat yaitu mengurangi konsumsi saat ini, memakan-makanan yang berkualitas rendah, dan memanfaatkan energi yang tersimpan dalam tubuh.

2. Timbunan yaitu mengumpulkan, melindungi, melestarikan, dan melindungi asset untuk pemulihan dan membangun kembali mata pencaharian.

3. Menguras yaitu berhutang pada toko yang menjual makanan atau menjual asset yang dimiliki.

4. Membuat variasi yaitu mencari sumber makanan seperti mengambil makanan yang ada di alam, berburu binatang, dan melakukan diversifikasi kegiatan kerja dan sumber pendapatan.

5. Mengklaim yaitu membuat klaim pada kerabat atau berhutang pada kerabat dan tetangga dengan niat baik akan mengembalikan suatu hari.

6. Bergerak yaitu melakukan tindakan seperti migrasi bergerak dari tempat satu ke tempat yang lain untuk mendapatkan pekerjaan. 
Berdasarkan bentuk-bentuk strategi nafkah dan strategi bertahan hidup maka penambang pasir di Dusun Citerate dapat dianalisis dengan menggunakan pendekatan tersebut. Berikut kerangka pemikiran yang digunakan untuk menjelaskan fenomena penambang pasir di Dusun Cirerate.

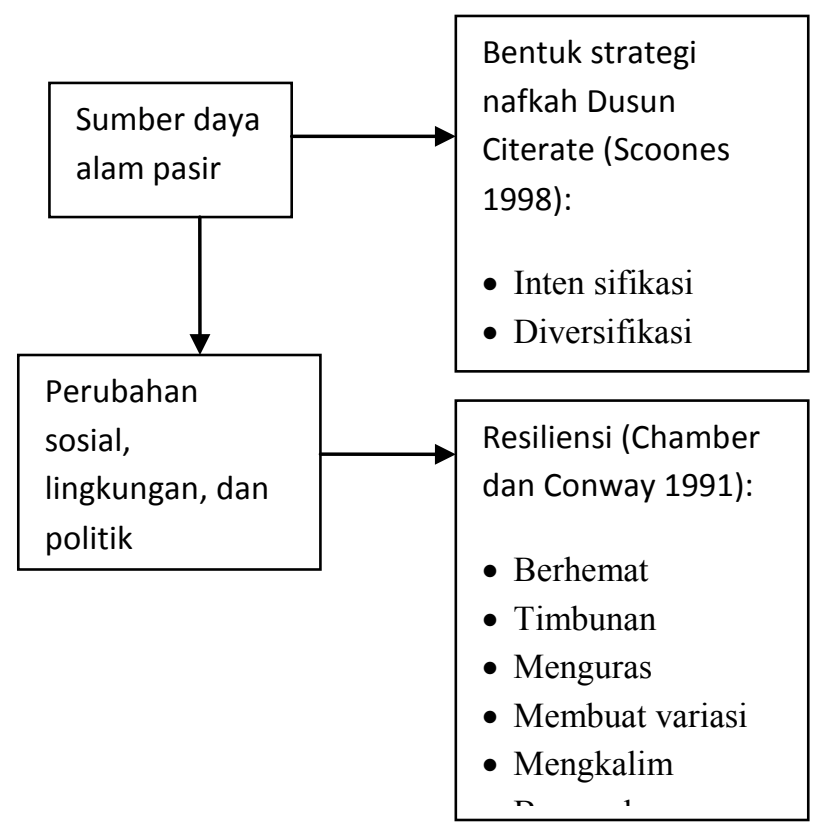

Gambar 1 Kerangka pemikiran

\section{HASIL DAN PEMBAHASAN}

\section{Strategi Nafkah dan Pelapisan Sosial Penambang Pasir di Dusun Citerate}

Berdasarkan ketiga bentuk strategi nafkah menurut Scoones (1998) maka diversifikasi dan migrasi dapat dikaitkan dengan strategi nafkah di Dusun Citerate. Pada dasarnya jenis mata pencaharian masyarakat Dusun Citerate adalah sebagai petani. Hasil pengamatan menunjukkan bahwa untuk menunjang perekonomian keluarga masyarakat memanfaatkan pasir di sekitar rumahnya yang konon dapat dijadikan bahan bangunan untuk dijual. Penambang pasir dapat dikatakan sebagai diversifikasi untuk menunjang perekonomian keluarga. Jenis pasir laut tersebut memiliki nilai jual yang tinggi, tidak heran jika pendiri IPPC memiliki lahan pasir seluas 2 hektar. Masyarakat yang memiliki lahan pasir luas tidak serta mengerjakan sendiri ketika ada pelanggan, namun biasanya mereka mempekerjakan buruh yang bertindak sebagai penggali dan pengangkut pasir. Pekerjaan sebagai buruh tambang pasir hanyalah sampingan sedangkan pekerjaan utama mereka adalah sebagai petani. Mereka melakukan aktifitas penambangan ketika pemilik pasir membutuhkan bantuan untuk menggali atau mengangkut pasir. Begitu pun dengan pemilik tambang pasir, salah satu tokoh menyebutkan bahwa menambang pasir adalah pekerjaan sampingan sedangkan pekerjaan utamanya adalah sebagai guru di salah satu sekolah dasar. Adapun masyarakat yang memiliki tambang pasir tidak begitu luas biasanya menggali dan mengangkut sendiri dibantu oleh pembeli pasir. Hal tersebut dikarenakan pembeli datang dari perseorangan yang dimanfaatkan sendiri bukan dari toko meubel atau toko batu bata yang akan dijual kembali.
Bentuk strategi nafkah yang terakhir adalah migrasi. Menurut Lee dalam Mantra (2013) migrasi dipengaruhi oleh empat faktor antara lain; faktor individu, faktor yang terdapat di daerah asal, faktor yang terdapat di daerah tujuan, dan faktor rintangan antara dengan daerah asal dengan daerah tujuan. Hal tersebut sesuai dengan apa yang terjadi di Dusun Citerate, bahwa masyarakat yang tidak memiliki kemampuan beradaptasi dengan bentuk strategi nafkah yang ada akan bermigrasi sebagai TKI atau TKW ke daerah-daerah sekitar Jawa Barat bahkan ke luar negeri. Hasil wawancara dengan salah satu tokoh perempuan menyebutkan bahwa saat belum menikah dirinya pernah merantau ke Jakarta untuk bekerja di salah satu pabrik sebagai karyawan. Namun saat sudah menikah dirinya mengaku tidak lagi merantau di Jakarta. Tokoh tersebut juga menyebutkan bahwa para perempuan terutama di Dusun Citerate yang lulus sekolah dan tidak memiliki keahlian khusus serta berasal dari perekonomian terbatas umumnya bermigrasi ke Jakarta dan sekitarnya. Tokoh perempuan tersebut mengaku bahwa setelah menikah dirinya bersama ayahnya juga memanfaatkan pasir di sekitar rumahnya untuk dijual sedangkan suaminya bekerja sebagai buruh tambak udang. Tambang pasir diakui olehnya hanyalah sebagai pekerjaan sampingan sedangkan pekerjaan seharihari bekerja sebagai pedagang makanan.

Strategi nafkah pada akhirnya menciptakan pelapisan sosial pada masyarakat. Istilah pelapisan sosial sering dikenal dengan stratifikasi sosial yang berarti suatu pembedaan penduduk atau masyarakat ke dalam kelaskelas secara bertingkat (Sorokin 1959 dalam Pandjaitan 2004). Pada dasarnya proses terbentuknya pelapisan pada masyarakat dikarenakan perbedaan kemampuan mengakses sumberdaya. Begitu pun pada masyarakat penambang pasir di Dusun Citerate dimana orang yang mampu mengakses sumberdaya digolongkan dalam lapisan atas. Golongan atas umumnya ditempati oleh pemilik pasir yang mampu mempekerjakan pekerja untuk menggali pasir miliknya. Golongan menengah ditempati oleh pemilik pasir namun tidak memiliki pekerja dalam arti dikerjakan oleh pemilik pasir sendiri dan dikelola oleh keluarga. Golongan bawah ditempati oleh penggali pasir dan penyekop atau orang yang memindahkan pasir ke dalam truk. Sejauh pengamatan ini dilakukan tidak terlihat adanya konflik yang terjadi diantara penambang pasir.

\section{IPPC Sebagai Kontrol Aktivitas Penambangan}

IPPC ini dibentuk sebagai keinginan para pemilik tambang pasir yang diinisiasi oleh Pak Tono agar mereka memiliki suatu wadah yang dapat mengorganisasikan aktivitas penambangan. Selain itu, IPPC diharapkan dapat berfungsi untuk mengurangi perebutan kerja antar penduduk yang bekerja sebagai pengeruk pasir. Pengurus IPPC Ini terdiri dari ketua, sekretaris yang merangkap menjadi bendahara, seksi lapangan, dan pengelola buruh penggali pasir. Seksi lapangan bertugas untuk mengatur dan mengontrol batas-batas penggalian pasir. Sementara pengelola buruh pengeruk pasir bertugas dalam mengatur jadwal kapan dan siapa penggali pasir yang akan bekerja, serta mengatur jam operasional IPPC. Dengan demikian, organisasi ini sudah terlihat terstruktur, dan diharapkan baik pengurus maupun penggali atau yang disebut sebagai buruh dapat bekerjasama dan bekerja seadil mungkin.

Sebagai organisasi, IPPC memiliki aturan-aturan dalam pengelolaan tambang pasir antara lain: 1) para pemilik lahan 
harus mengetahui dengan jelas batas-batas lahannya sesuai dengan sertifikat yang mereka miliki, 2) penggali maupun pemilik yang menggali pasir tidak diperbolehkan untuk melewati batas lahan penggalian, dan 3) perlu diketahui peruntukkan lahan selain digunakan untuk tambang pasir akan dijadikan sebagai lahan apa pada musim hujan. Aktivitas penambangan hanya dapat dilakukan saat musim kering karena sifat pasir pada musim hujan akan lengket dan sulit untuk digali. Pada musim hujan, pemilik lahan perlu memiliki strategi lain agar lahan pasir yang dimiliki tetap dapat digunakan. Cara yang dilakukan adalah menjadikan lahan pasir tersebut sebagai kolam ikan atau untuk sawah. Syarat lahan yang akan digunakan untuk sawah adalah tidak terlalu dalam ketika melakukan penggalian. Sementara jika lahan tersebut akan digunakan untuk kolam ikan pada musim kering, maka penggalian pasir pada lahan tersebut perlu lebih dalam.

Persoalan tapal batas selalu ditemukan dalam aktivitas penambangan pasir. Hal ini dapat terjadi karena beberapa kemungkinan yaitu: 1) penggali pasir yang bukan pemilik lahan tidak mengetahui secara jelas batas-batas lahan mana yang termasuk dalam lahan si pemilik; 2) menggali pasir di sekitar tapal batas tidak serta merta selalu lurus sesuai tapal batas, hal ini karena tapal batas hanya terlihat di permukaan tanah. Kesalahan dalam memahami tapal batas ini selalu menimbulkan permasalahan dan keributan antar pemilik lahan. Pada kasus seperti ini, IPPC memiliki fungsi sebagai mediator antar penduduk yang bermasalah tersebut. Penyelesaiannya dilakukan melalui musyawarah antar anggota IPPC. Namun fungsi IPPC ini hanya berlaku bagi para anggotanya saja, yaitu pemilik lahan yang bersedia untuk menjadi anggota IPPC. Sementara tidak semua pemilik lahan di Dusun Citerate tergabung dalam IPPC.

Secara nyata, analisis ekologi politik dalam pengelolaan sumber daya pasir melalui IPPC ini tampak. Menurut Bryant dan Bailey (2000) dalam Kuswijayanti et al (2007), ekologi politik digunakan untuk melakukan penyelidikan terhadap bekerjanya kekuatan-kekuata yang membentuk konfigurasi kontelasi politik ekologi di suatu kawasan. Adanya aturan-aturan dan bagaimana IPPC dapat mengorganisir pengelolaan lahan pasir merupakan kajian yang menunjukkan bahwa ada kekuatan politik didalamnya.

\section{Pengelolaan Tambang Pasir oleh IPPC}

Pengelolaan tambang pasir sebelum dan setelah adanya IPPC jelas menunjukkan perbedaan. Selain terikat pada aturan-aturan tapal batas, anggota IPPC juga terikat dalam mekanisme jual beli pasir yang ditetapkan dalam IPPC. Setelah IPPC terbentuk, mekanisme jual beli pasir mulai menggunakan sistem karcis. Mekanismenya, sebelum mengambil pasir para pembeli tersebut harus membeli tiket terlebih dulu di pos yang didirikan oleh IPPC. Setelah memperoleh karcis, para pembeli berhak menggunakan jasa penyekop/ buruh gali yang sudah terdaftar dalam IPPC.

Melalui sistem karcis ini, uang pembayaran pasir tidak langsung diberikan kepada pemilik lahan, melainkan melalui pos IPPC terlebih dulu. Pasir tersebut dikenai harga sekitar 150 ribu untuk truk yang berukuran tiga atau empat kubik dan dengan memberikan upah sebesar 60 ribu rupiah untuk penyekop. Jumlah penyekop yang dibutuhkan biasanya satu orang. Namun jika ada dua orang penyekop, upah tersebut dibagi dua sehingga masing-masing penyekop memperoleh upah 30 ribu per truk ukuran tiga atau empat kubik. ${ }^{1}$ Sementara harga pasir untuk ukuran enam kubik sekitar 250 ribu rupiah dan memberikan upah untuk penyekop sebesar 80 ribu rupiah. Penyekop yang dibutuhkan untuk mengangkut pasir dengan truk berukuran enam kubik tersebut adalah dua orang, sehingga masingmasing penyekop memperoleh upah sebesar empat puluh ribu rupiah. Harga pasir tersebut merupakan harga bersih yang diterima oleh pemilik lahan, tidak termasuk upah penyekop, penggali, maupun biaya lainnya.

Pasir ini diperjualbelikan kepada masyarakat sekitar maupun masyarakat yang berada di luar Sukabumi. Selain itu, pasir ini juga dijual kepada perusahaan bata yang berada di luar Sukabumi. Biasanya perusahaan tersebut membeli pasir dari pemilik lahan terluas, hal ini karena kebutuhannya terhadap pasir juga tinggi. Pembeli pasir dalam skala besar diberikan kebebasan untuk membawa alat penggali sendiri. Biasanya mereka menggunakan "Beko" yang mereka sewa sendiri di luar biaya yang dikeluarkan untuk membeli pasir dan upah untuk penyekop. Penyewaan alat tersebut dilakukan oleh pembeli dan tidak melibatkan pemilik lahan maupun IPPC. Biasanya harga sewa alat "Beko" tersebut sekitar 450 ribu per jam dan menghasilkan pasir kira-kira 25-30 truk berukuran tiga kubik. Hasil galian pasir ini juga tergantung pada kepadatan pasir. Jika kepadatan pasir tinggi, maka hasil galian akan mencapai ukuran truk enam kubik. Sebaliknya, jika kepadatan pasir rendah, kemungkinan penggali hanya memperoleh pasir sebanyak truk berukuran tiga kubik. Begitu pula dengan truk yang digunakan, IPPC maupun pemilik lahan tidak menyediakan truk, namun pembeli membawa sendiri alat transportasi yang digunakan.

Pajak yang dikeluarkan untuk penambangan pasir ini dihitung per ton pasir yang digali setiap bulan. Perhitungan ini berdasarkan aturan yang telah dibuat oleh Dinas Pertambangan Kabupaten Sukabumi. Besarnya pajak yang dikeluarkan sesuai dengan jenis pasir yang digali di dusun ini sebesar 7.000 rupiah per ton pasir per bulan. Dengan adanya pajak tersebut, penambangan pasir ini memberikan pemasukan bagi Kabupaten Sukabumi. PDRB kabupaten sukabumi ${ }^{2}$ khususnya di pertambangan terus naik setiap tahunnya. Ini digambarkan pada tahun 2007, PDRB Kabupaten Sukabumi sebesar 378,452 juta atau 4,91\%. Data tahun 2008 persentasenya menurun menjadi 4,86\% namun jumlah nya meningkat sebesar 389.910 juta. Tahun 2009 jumlahnya kembali meningkat 401.369 atau 4,83\%, tahun 2010 jumlahnya 406,468 juta atau $4,70 \%$ dan pada tahun 2011 berjumlahnya 414,769 juta atau 4,61\%. Pendapatan yang diterima Pemerintah dari pertambangan pasir setiap tahunnya naik, mengindikasikan bahwa kegiatan menambang pasir semakin tinggi intensitasnya. Seperti halnya di dusun citerate, IPPC membayar retribusi pajak sebesar Rp.7000/ton pasir pajak kepada Dinas terkait.

\section{Strategi Bertahan Hidup}

Strategi bertahan hidup atau yang sering dikenal dengan istilah resiliensi merupakan kemampuan kelompok atau masyarakat untuk mengatasi tekanan eksternal dan gangguan sebagai akibat dari perubahan sosial, politik, dan lingkungan (Jansen 2007 dalam Cote 2012). Adapun

1 Harga pasir maupun upah buruh untuk truk berukuran empat kubik sama dengan truk berukuran tiga kubik.

2 Lihat http://regionalinvestment.bkpm.go.id/newsipid/ ekonomipdrb.php?ia $=3202 \&$ is $=43$ 
bentuk-bentuk strategi bertahan hidup masyarakat dalam menghadapi lingkungannya menurut Chamber dan Conway (1991) adalah berhemat (mengurangi konsumsi saat ini), timbunan (melindungi dan mengumpulkan asset), menguras (menjual asset), membuat variasi (melakukan diversivikasi pekerjaan atau sumber pendapatan), mengklaim (mencari pinjaman), dan bergerak (migrasi). Berdasarkan bentuk strategi bertahan hidup tersebut maka yang banyak dilakukan oleh masyarakat Dusun Citerate dalam menghadapi tekanan adalah melakukan variasi pekerjaan.

Diversivikasi pekerjaan sebagai strategi bertahan hidup dilakukan oleh masyarakat ketika lahan pasir sudah habis ditambang. Sebagai bentuk kepedulian mereka terhadap lingkungan maka lahan pasir yang sudah habis ditambang dijadikan sawah atau kolam ikan. Namun berbeda lagi dengan diversivikasi yang dilakukan oleh buruh tambang. Pekerjaan sebagai buruh tambang adalah pekerjaan sampingan sehingga ketika lahan pasir sudah habis maka mereka akan kembali melakukan pekerjaan utama seperti bertani dan menjadi buruh tambak udang.

\section{KESIMPULAN}

Strategi nafkah yang dilakukan oleh masyarakat Dusun Citerate yaitu dengan diversifikasi dan migrasi. Diversifikasi yang dilakukan yaitu dengan memanfaatkan pasir laut sebagai sumber pendapatan mereka. Perbedaan dalam mengakses sumberdaya pasir menyebabkan timbulnya pelapisan diantara penambang pasir. Terdapat tiga golongan dalam pengelolaan pasir yaitu golongan atas, golongan menengah, dan golongan bawah. Golongan atas ditempati oleh pemilik pasir dengan lahan pasir yang luas sehingga memiliki tenaga kerja seperti penyekop dan penggali pasir. Golongan menengah ditempati oleh penambang pasir yang tidak memiliki tenaga kerja. Golongan bawah ditempati oleh buruh pasir seperti penyekop dan penggali pasir.

Bentuk strategi nafkah yang kedua adalah migrasi. Migrasi banyak dilakukan oleh perempuan yang sudah tamat sekolah namun tidak memiliki keahlian khusus yang dapat diterapkan di desanya sehingga memilih untuk bermigrasi. Umumnya perempuan yang sudah menikah akan kembali ke daerah asal dan berdagang. Selain itu di Dusun Citerate juga dikenal dengan strategi nafkah keluarga. Dalam satu keluarga terdapat beberapa orang yang bekerja, misalnya suatu keluarga yang didalamnya terdapat orangtua dan anak yang sudah menikah namun tinggal dalam satu rumah. Hasil pengamatan menunjukkan bahwa Bapak bekerja sebagai petani dan memiliki usaha sampingan yaitu menjual pasir di sekitar rumah, anak bekerja sebagai pedagang, sedangkan menantu bekerja sebagai buruh di tambak udang.

Lebih lanjut hasil pengamatan menunjukkan bahwa lahan pasir tidak dapat berlangsung lama. Jangka waktu yang tidak lama menyebabkan organisasi IPPC sebagai penggerak aktifitas penambangan pasir di Dusun Citerate menghimbau pada pemilik lahan pasir untuk memanfaatkan lahan bekas tambang pasir menjadi sawah atau kolam ikan. Selain itu buruh yang bekerja sebagai penyekop dan penggali terpaksa kehilangan pekerjaan sampingannya sehingga mereka kembali ke pekerjaan utama sebagai petani atau buruh tambak udang. Keadaan tersebut merupakan hasil dari perubahan lingkungan dimana masyarakat berusaha untuk tetap eksis dalam mencari sumber penghidupan yang disebut dengan resiliensi atau strategi bertahan hidup. Strategi bertahan hidup yang dilakukan oleh masyarakat Dusun Citerate dikategorikan sebagai variasi pekerjaan atau diversivikasi.

\section{DAFTAR PUSTAKA}

[BKPM]. Display Ekonomi PDRB Kabupaten Sukabumi. [Internet]. [dikutip pada 24 Januari 2015]. Dapat diunduh dari: http://regionalinvestment.bkpm.go.id/ newsipid/ekonomipdrb.php?ia $=3202 \&$ is $=43$

Bappeda Kabupaten Sukabumi. [Internet]. [diunduh tanggal 24 Januari 2015]. Tersedia pada: http:// bappeda.sukabumikab.go.id/gu.php

http://regionalinvestment.bkpm.go.id/newsipid/ ekonomipdrb.php?ia $=3202 \& i s=43$

http: //sukabumikab.bps.go.id/index. php?hal=tabel\&id=3.1

journal.ipb.ac.id/index.php/sodality/article/view/5938

Chambers, R, Conway, GR. 1991. Sustainable Rural Livelihood: Practical Concepts for The 21 $1^{\text {st }}$ Century. [Discussion Paper]. IDS Agricultural and Rural Problems; food security; environment 296. Institute of Development Studies; Paper; 296; December 1991. [interent]. [dikutip pada 21 Februari 20157. Dapat diunduh dari: http://www. ids.ac.uk/publication/sustainable-rural-livelihoodspractical-concepts-for-the-21st-century

Cote, M, Ninghtingale, AJ. 2012. Resilience Thinking Meets Social Theory: Situating Social Change in Socio-Ecological Systems (SES) Research. [Jurnal]. Progress in Human Geography: 36(04): $475-$ 489. [interent]. [dikutip pada 21 Februari 2015]. Dapat diunduh dari: http://www.researchgate. net/publication/236648284 Resilience thinking meets social theory Situating change in socioecological systems \%28SES\% $\%$ research

Kuswijayanti ER, Dharmawan AH, Kartodihardjo Hariadi. 2007. Krisis-Krisis Socio-Politico-Ecology di Kawasan Konservasi: Studi Ekologi Politik di Taman Nasional Gunung Merapi. Sodality: Jurnal Transdisiplin Sosiologi, Komunikasi, dan Ekologi Manusia Vol. 01, No. 01 April 2007, p 41-66. [Internet]. [diunduh tanggal 20 Januari 2015].

Mantra, IB. 2013. Demografi Umum. Pustaka Pelajar. Yogyakarta

Narwoko, Dwi. J \& Bagong Suyanto.2004. Sosiologi : Teks Pengantar \& Terapan. Jakarta: Kencana. Hal :155156.

Scoones, I. 1998. Sustainable Rural Livelihoods A Framework for Analysis. [Paper]. IDS Work Paper 72. [Internet]. [dikutip pada 20 Februari 2015]. Dapat diunduh dari: http://mobile.opendocs.ids. ac.uk/opendocs/handle/123456789/3390.

Wallace, Ruth.A.Wolf, Alison.2005. Contemporary Sociological Theory Expanding The Classical Tradition. Pearson Education, Inc. Upper Saddle River, New Jersey. 